\title{
Serpiente y propaganda augustea en Hispania
}

\author{
Ana $\mathrm{M}^{\mathrm{a}}$ VÁzQUEZ HoYs \\ Universidad Nacional de Educación a Distancia \\ avhoys@yahoo.es
}

\section{RESUMEN}

Planteamos aquí la posibilidad de que la figura de la serpiente representada en algunos materiales arqueológicos que conocemos de época augustea en Hispania forme parte interesada de la propaganda imperial y los mitos que el propio Octavio quiso difundir acerca de su origen divino y la Aurea Aetas que su gobierno traía a Roma. Suponemos además que dicha propaganda pudo utilizar interesadamente la figura de este animal, según su figura significase en cultos autóctonos de diversas zonas de la Península Ibérica Hispania o su relación con diversos personajes históricos como Alejandro Magno, Marco Antonio o Pompeyo.

Palabras clave: Serpiente. Propaganda imperial. Arqueología. Augusto. Agathoaimon.

\section{Serpent and Propaganda of Augustus in Hispania}

\begin{abstract}
ABSCTRACT
We refer here to the possibility that the figure of the serpent which appears on some archaeological materials from the time of Augustus in Hispania formed an interesting part of the imperial propaganda and a myth that Octavius himself would have liked to spread in relation to his divine origin and the Aurea Aetas that his government was bringing from Rome. We suppose also that such propaganda may have used the figure of this animal (here a good serpent, genius loci/ agathodaimon/genius Augusti) in different ways out of interest, depending on how the figure was being used in local cults within different parts of the Iberian Peninsula Hispania or based on its relation with diverse historical figures like Alexander the Great, Marcus Antonius, or Pompeius.
\end{abstract}

Key Words: Serpent. Snake. Imperial propaganda. Archaeology. Augustus. Agathodaimon.

Sumario: Introducción. Serpientes y dioses en cultos grecoitálicos y la propaganda augustea. Hijos de la Serpiente. Apolo contra Dionisio. 1. Ejemplares arqueológicos hispanos de época augustea con serpientes. 2. La serpiente en la propaganda augustea emeritense. Capiteles corintios con serpiente y el relieve de Pancaliente. 3. La serpiente en cultos mediterráneos y próximo-orientales: serpiente buena/serpiente mala. 4. La serpiente, Pompeyo y Augusto en Carthago Nova. Genius Augusti, Agathodaimon e Imitatio Alexandri. 5. Conclusiones. Diversas serpientes augusteas, diferentes mensajes, según las zonas. 
“...un mutamento di sistema politico, possa condurre allo sviluppo di un nuovo linguagio visivo, che riflette e nello stesso tempo condiziona in modo esenziale 1' evoluzione de la mentalitá"

Paul Zanker Augusto e il potere delle immagini,1989

\section{Introducción. Serpientes y dioses en cultos grecoitálicos y propaganda augustea. Hijos de la Serpiente. Apolo contra Dionisio}

La serpiente es un animal polisémico, cuya imagen, más allá del carácter vil y temible, universalmente rechazado con que la caracterizaba Aristóteles (Arist., H.A. I 88b 16), fue sin embargo utilizada a lo largo de la Historia de las Religiones y las ideas políticas con un significado ambivalente, ${ }^{1}$ simbolizando ideas o conceptos, a veces contrarios, como vida, muerte, resurrección, eternidad, fertilidad, fecundidad e incluso expresando el carácter divino de personajes con ella relacionados. En otras ocasiones, este animal acompaña a una divinidad, indicando sus atributos o características, bien demoníacas, bien salutíferas o salvíficas, ${ }^{2}$ como en el caso del dios de la salud Asclepio-Esculapio o su antecesor, el dios oriental Ninginzzida, de cuyo caduceo, como del de Mercurio, forman parte las serpientes, animales cuya imagen ha llegado hasta nuestros días como símbolo de la salud/farmacia/curación. En el mundo antiguo diversos héroes y dioses fueron representados en forma de serpiente

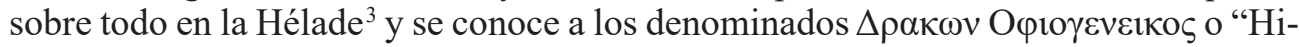
jos de la Serpiente", como en la leyenda recogida por Estrabón (Geografía 13.1.14) y Eliano (Aelian, Nat. anim. 12.39), sobre una joven llamada Halia que concibió de una gran serpiente cuando visitaba una arboleda sagrada de la diosa Artemisa un hijo llamado Ophiogenes, "Hijo de la Serpiente", antepasado de la tribu de los Ophiogenes que habitaron la región. Este presunto coito ofidiomórfico ${ }^{4}$ se utilizaba a veces también como una forma de "ensueño de poder", como el de Atia en la concepción de Augusto por el dios Apolo en forma de serpiente (Suet., Aug. 94), el que engendró de Nicoteleis a Aristómenes, al que los mesenios consideraban un héroes, hijo de una serpiente que podía ser o Zeus o Heracles (Paus., VI 14.7.8) o el coito ofidiomórfico de Aristodama, madre de Arato de Sición, hijo también de Asclepio en forma de serpiente (Paus., IV 17.8) y en Roma los gemelos Cómodo y Antonino, cuya madre soñó que paría dos serpientes, o la leyenda similar relativa a Alejandro Severo y Galieno. ${ }^{5}$

No resultó muy extraño, pues, que en Macedonia, país en el que las serpientes eran habituales como animales domésticos, se divinizase a Alejandro Magno, atribuyéndose su paternidad a Zeus en forma de serpiente, en este caso Zeus Amón, un dios egipcio sincretizado con el Zeus griego (Plut. Vida 2), leyenda tal vez muy posterior

\footnotetext{
1 Bodson 1978, 68-92.

2 VÁzQuez Hoys 1992.

3 Mitropoulou 1977, Vázquez Hoys 2006b, 479-93.

4 Gil Fernández 2002, 20, 26.

5 LoRCH 1993, 1997, 2000; Lozano 2008.
} 
al rey o incluso inventada por la misma Olimpia (Plut., Alex. 2.4, Paus., IV 14.8; Just., Hist. Phil. Alex. XII 16.2) ${ }^{6}$ o por el mismo Alejandro, aprovechando en su favor y para su glorificación la opinión de su maestro Aristóteles, de que los grandes hombres son considerados por los demás "como dioses" (Política III 8.1). Aprovechaba así el rey la creencia de que la serpiente doméstica era el "buen espíritu protector del hogar", el Agathos Daimon. Y era muy popular, de entre los citados dioses y héroes en forma de serpiente, el dios tracofrigio Zagreo, "el primer Dioniso", un dios órfico cuya leyenda pertenece a la teología de estos misterios, considerado generalmente como hijo de Perséfone y Zeus serpiente, el "primer Dioniso", al que Esquilo denominaba "Zeus subterráneo", asimilándolo a Hades, ${ }^{7}$ el mismo dios para Clemente de Alejandría (Protrep. II 16; Eurip., Bac. 102-4, 697-8). Siglos después, Augusto se divinizaría copiando la filiación ofídico-divina de aquellos ilustres personajes históricos que le habían precedido. Una filiación que en la casa imperial romana no terminaría con él, como arriba dijimos.

Pero además de para servir de disfraz a dioses juguetones (por no aludir a la poco nombrada ofidiofilia femenina que estas leyendas esconden y disimulan), alguna vez la serpiente era considerada también un animal profético, como en el caso de Livio (1.56) que narra la aparición en Roma de una serpiente profética en época de Tarquinio el Soberbio, aunque dicho animal a veces no acertase mucho, como cuando se predijo con ella a Aníbal la destrucción de Italia (Liv. 21.22), aunque sí fue un acierto según el mismo autor (Liv. 25.16) el presagio dado a Tiberio Graco, quien antes de salir de Lucania recibió de este animal un repetido aviso de mal agüero y precaución, ya que justo al terminar de hacer un sacrificio, dos enormes serpientes se deslizaron de improviso hacia el altar y tocaron el hígado de la víctima... hasta tres veces... presagio negativo que Tiberio ignoró, siendo traicionado por un lucano llamado Flavo, que le llevó a una trampa y a la muerte a manos de Magón.

Otras veces la relación de la serpiente con algunos personajes históricos podía atribuirse a un signo del favor divino. Así, Tácito (An. XI 10) recoge el rumor de que una serpiente había cuidado a Nerón durante su infancia, hecho que parece basarse en la arriba aludida creencia de que la presencia de una serpiente significaba el carácter más que humano (¿divino?) de una persona. ${ }^{8}$

Con toda seguridad el entorno de Octavio y su madre y ellos mismos conocían estas antiguas creencias, muy extendidas en dos zonas muy relacionadas con ellos: la citada región greco-traco-macedonia, no solo porque Octavio Turino, respectivamente marido de Atia y padre del futuro Augusto, fue procónsul de esta provincia romana, y la zona de Lanuvio, de donde era originaria la familia, con el célebre santuario de la diosa Juno Sospita y su monstruosa serpiente oracular. ${ }^{9}$

\footnotetext{
6 VÁzQuez Hoys 1993, 264 y n.4: ID. 2005a y b.

7 Grimal 2008, s.v.

8 VÁzquez Hoys - García Vaso 1990, 99.

9 Hermans 2012.
} 

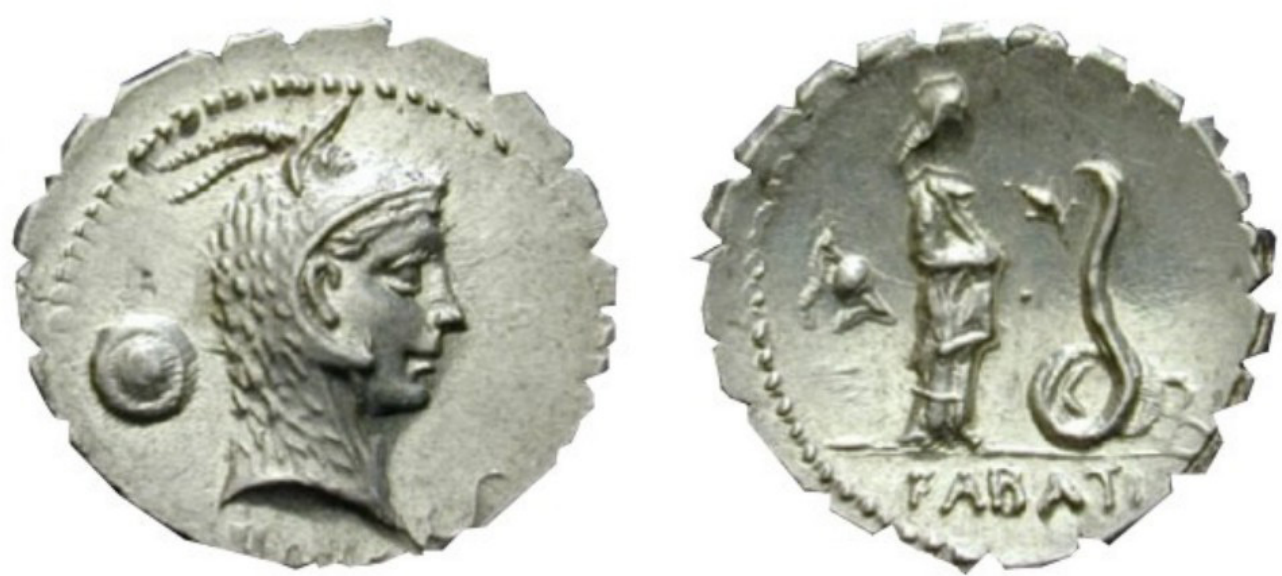

Fig. 1.Denario de la gens Roscia, 64-58 a.C. Crawford 142/1.

Según una leyenda, Lanuvium estaba dominada por una serpiente monstruosa a la que alimentaban con ofrendas las jóvenes vírgenes de la ciudad, que con la "ayuda" y aceptación de la ofrenda por parte de dicha serpiente probaban su inocencia. Este animal, que aún hoy aparece junto a la diosa en el actual escudo de la ciudad, estaba en la antigüedad representado en los denarios dentellados de la gens Roscia, que dio a Roma célebres personajes. ${ }^{10}$ (Fig. 1). Dicho templo de Lanuvium fue uno de los santuarios-banco que como abajo veremos, invirtieron bastante oro en las primeras campañas de Octavio. Una serpiente podía ser también para los romanos signo y prueba de amor, fidelidad conyugal y fecundidad y así se consideró cuando aparece en historias como la de Tiberio Sempronio Graco, el cual fue conminado por los arúspices a los que había consultado a sacrificar una de las serpientes que había hallado en su lecho conyugal, con lo que se interpretó que morirían él o su esposa, Cornelia Africana. ${ }^{11}$ Al preferir Tiberio matar a la que le representaba a él, con lo que prefería su muerte a matar a la que representaba a su mujer, mucho más joven, salvó la vida a ésta y al poco tiempo murió él, dejando doce hijos (Plut., Tib.Graco 1.2; Val. Maximo, IV 6.1, Cic., Div. II 3.6, Auc., De uir ill 57.4, Plin., NH 122).

Nada que ver con dicha tradición romana de fidelidad y amor conyugal fue lo que el entorno de Augusto inventó sobre su padre-serpiente. Puestos a glorificar al joven Octavio, poco importaba que a su madre le inventasen un amante ofídico, que convertía al ya fallecido Octavio Turino, padre del joven, en un marido engañado. Este relato, que glorificaba al joven, hacía de Atia un personaje similar a la gran Olimpia de Épiro, ${ }^{12}$ si bien el amante ofídico era ahora el mismísimo Apolo, disfrazado de

10 Crawford 1975, s.v. snake 412, 472, 480; 39, 42, 69, 72, 379, 427, 442, 453,476, Juno Sospita 491, 412-1; Syndeham 1952, 915. L. Roscius Otho era partidario de Pompeyo. Y Fabato fue comandante de la Legio X con César. Esta gens tuvo bastante importancia en época imperial en Lusitania. Cfr. GonZÁlEZ Herrero 2003, 623-5; 2006, 53-58.

11 BAYET 1971, 376.

12 VÁzQuez Hoys 2005a y b. 
serpiente como otrora Zeus, dios ahora desplazado, siguiendo el interés augusteo por el dios de Delfos y tal vez por sus riquezas.

Octavio sería, así pues, un nuevo "Hijo de la Serpiente", con lo que copiaba no solo al extranjero, aunque admirable, Alejandro Magno, en lo que a padre divinoserpentiforme y madre de extraños gustos sexuales se refería, sino también a otro imitador romano de Alejandro: Escipión Africano (Liv., 26.19.4-7; Gel., VI 1, Suet., 2.94). ${ }^{13}$

Entroncaba así también con la tradición romana del presagio de la serpiente considerado como signo de poder (Plut., Alejandro 3 y 27, Quint. Cur., X 5),${ }^{14}$ elemento mítico común a otros héroes de la antigüedad como el citado Escipión y el tracio Espartaco (Plut., Cras. 8.3), que en la narración de Dión Casio está unida al origen divino del hijo de Atia (Cas. Dio, XLV 1.2; Suet., Aug. 94.3-4), la principal defensora del origen "apolíneo" de su hijo, un omen que presenta además una gran cantidad de elementos significativos relacionados con el resto de los numerosos omina imperii de Augusto, elaborados a posteriori, en los que la serpiente también estaba presente. ${ }^{15}$

En la Península itálica este animal era también bien conocido en diversos cultos, como los de los Marsos, inmunes como los Psillos norteafricanos a la ponzoña de las serpientes venenosas ${ }^{16}$ o la citada Juno de Lanuvium, localidad cercana a Velletri, y su célebre oráculo de la serpiente (Proper., 4.8; Ael., 23.1), a pocos kilómetros al sur de Roma, lugar de origen de la familia de Augusto. La gens a la que el joven Octavio pertenecía estaba protegida por el dios Apolo, ${ }^{17}$ dios que para la sociedad romana de su época, representaba la moral y la disciplina, frente a un depravado Marco Antonio/Dioniso ejemplo de inmoralidad y desenfreno, una iconografía que se aprecia en los denarios emitidos por ambos, con un lenguaje fácilmente comprensible para el pueblo. ${ }^{18}$ Así, en relación a Marco Antonio, Octavio adoptaba un estilo más fino (asiático-egipcio sg. Dion Casio 48.30) como dios profético de la nueva era de Augusto, ${ }^{19}$ unido en Delfos a la serpiente Pitón, por lo que la serpiente utilizada por la propaganda augustea ha sido considerada generalmente un motivo apolíneo, como abajo veremos, puesto que la iconografía apolínea se utilizó ya en los primeros denarios acuñados tras la batalla de Accio, en el último tercio del siglo I a.C., con los que Octaviano pagó a sus tropas y otros ejemplares acuñados en Lugdunum. ${ }^{20}$ También al dios Apolo dedicó Augusto uno de los tres grandes templos que construyó ex novo para los dioses romanos: a Mars Ultor, en el Foro de Augusto, expresión más clara de la propaganda de su familia, ${ }^{21}$ en cuyos capiteles corintios más internos ya se encuentra la figura de la serpiente, a Júpiter Tonante en el Capitolio (Suet., Aug. 29.1-2) y el templo del Palatino, que comunicaba directamente con su residencia en

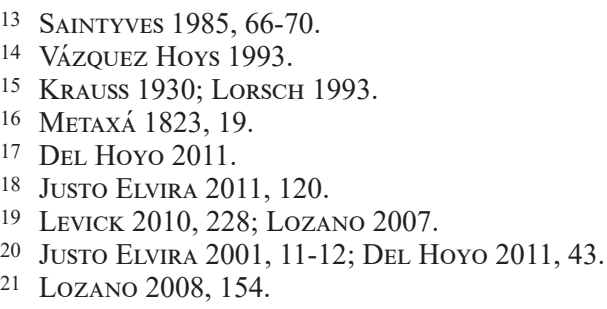


dicha colina romana, según un modelo helenístico, por un voto tras vencer a Sexto Pompeyo cerca de un templo de Diana. ${ }^{22}$ En cuanto a la serpiente en la propaganda oficial augustea, ya en el Ara Pacis, ${ }^{23}$ la iconografía de este animal está presente de dos formas: "buena", como pequeñas serpientes benéficas, formando parte de la fauna y la vegetación que personifican Tellus, la Abundancia y la actual Aurea Aetas ${ }^{24}$ y "mala", como nota discordante en tanta placidez, en forma de cobra maléfica que ataca un nido con pajarillos, símbolo tanto de la potencial fragilidad de la época y el orden impuesto por Augusto al mundo romano, al que protege como el nuevo Aquiles cantado por Homero (Il. 2.308-20, 9.323), como de la incertidumbre de la sucesión imperial en el momento de la consagración del Ara Pacis. ${ }^{25}$ La serpiente a la que llamamos "buena" por oposición a la cobra "mala", es para estos autores una imagen de la similitud de Augusto con Eneas, y como él, ${ }^{26}$ y tema de la Edad de Oro en Horacio y Virgilio, el refundador de Roma. Y frente a Oriente y Egipto, el nuevo Alejandro, fundador de Alejandría y monarca ideal. ${ }^{27}$

En nuestra opinión, sin embargo, la cobra atacando el nido en el Ara Pacis, (Fig. 3) además de recordar el cuidado de Troya-Roma por Augusto-Aquiles o la potencial fragilidad de la sucesión augustea, ${ }^{28}$ puede también significar el peligro, ya vencido, que habían representado Antonio y Cleopatra, la reina de Egipto, protegida por la cobra uraeus y muerta por un áspid. Los reinos y tesoros de aquella, madre de un hijo de César, Cesarión, y la otra gran rival de Roma, estaban ahora en poder de Augusto. Pero además, "defender a Roma de la poderosa serpiente" era también un buen motivo de propaganda, no solo en la ya citada alusión a Asia y Egipto, sino también frente a otra gran rival: Cartago, cuya moneda estaba en el área económica ptolemaica, es decir, "de la serpiente egipcia". Y no solo eso, sino que además, en Oriente, Octavio acuñó cistóforos, con su imagen y la cista mística dionisiaca (utilizada por Antonio) entre dos serpientes (Liv., 37.46.58; 39.0.7; Cic., ad Att. II 0.6; XI 0.1). El hecho de aparecer en una moneda con serpientes y Dioniso en la que antes aparecía Antonio, en nuestra opinión, tal pueda interpretarse de una de las formas siguientes (o ambas a la vez): "Yo Octavio domino políticamente a Antonio/Dioniso" y/o "yo, Octavio, sustituyo a Antonio-Dioniso en los negocios de los Dionisyaikoy technitai", las poderosas cofradías religioso-económicas que emitían originalmente en Éfeso las monedas con la cesta mística de Dioniso y serpientes ${ }^{29}$ las dos últimas monedas acuñadas con el tipo de la cesta mística según Lenormant. ${ }^{30}$

Así pues, aunque son muchos los ejemplos que podríamos citar sobre la utilización política, religiosa o económica a lo largo de las Historia de la Religiones y de algunos personajes, incluido Augusto y su entorno, de la figura de este animal, al que tantos

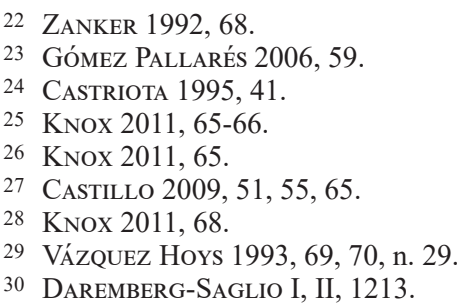


trabajos hemos dedicado hasta ahora (cfr. Bibliografía), creemos poder afirmar que la figura de la serpiente "buena"/benéfica, signo de riqueza, fertilidad y bonanza, como se supone significan las pequeñas serpientes representadas en el Ara Pacis, también fue utilizada por la propaganda augustea para representar o transmitir diferentes mensajes visuales en Hispania, de cara a los diversos significados que debía tener este animal en las diferentes zonas de la Península Ibérica, de la que examinaremos, sin realizar un catálogo exhaustivo, lejos de nuestro actual propósito, algunas piezas arqueológicas o numismáticas de época tardorrepublicana, augustea y altoimperial, tratando de entender su posible significado, teniendo en cuenta que la imagen de la serpiente fue usada por todo el Mediterráneo desde época inmemorial con un sentido polisémico con distintos propósitos, tanto religiosos como económico, ya que, como recuerda Turcan, y en relación a la monedas con serpientes que abajo comentaremos, a veces la figura de una divinidad en una moneda, puede tener no solo y exclusivamente un significado religioso, sino también político, como ocurre, por ejemplo, en las series acuñadas por Galieno en Colonia en el año 258-259, ya que al menos en época romana, las monedas eran un instrumento de propaganda que, al circular de mano en mano, era vehículo de los esloganes de cualquier tipo que el poder emisor quería difundir. ${ }^{31}$

\section{Ejemplares arqueológicos hispanos de época augustea con serpientes}

En toda Iberia, denominada Ophiussa, "tierra de serpientes", por Avieno, al menos parte de Lusitania, la figura de la serpiente era usada/adorada en época prerromana a nivel popular y posiblemente reverenciada como divinidad, o como animal que representaba unos poderes cuya naturaleza sobrenatural se presupone, en todo caso por comparación a lo que de ella se sabe en momentos posteriores, dada la carencia de fuentes escritas intelegibles. ${ }^{32}$

Ya en época romana, se constata la presencia de este animal en fuentes epigráficas ${ }^{33}$ $\mathrm{y}$ arqueológicamente al menos en materiales que conocemos en dos zonas particularmente interesantes: Lusitania (Emerita Augusta), donde una divinidad prerromana, Ataecina, se sincretizó con la romana Proserpina, a veces como Ceres, representada con serpientes ${ }^{34}$ y la Tarraconense (Carthago Nova) en algunas de cuyas monedas pompeyanas aparece representado este animal, tal vez relacionado con alguna divinidad indígena relacionada con ella, sincretizada con la Juno romana adorada en Elche, similar a la de Lanuvio tan próxima a Augusto, una diosa "ajena a Roma" cercana en Iberia a divinidades púnico-orientales..$^{35}$ Los ejemplares en los que apreciamos la figura de la serpiente son: en el centro de todas las rosetas centrales del piso superior de las cuatro caras de los capiteles corintios de las columnas y las pilastras que se con-

31 VÁzquez Hoys 1993, 60-61; Del Hoyo 2011, 41.

32 VÁzQuez Hoys 1980, 1994, 1999, 2006, 2006 a, 2007.

33 VÁZQUEZ HoYs 1994.

34 VÁzQuez Hoys 1995, 250.

35 VÁzquez Hoys 2000 b, 1997,1999; VÁzquez Hoys - Poveda Navarro 1995-2000. 
servan del Pórtico del Foro de Mérida, que suponemos muy similares a los tremendamente desgastados del denominado templo de Diana de Mérida, donde creímos verla hace años, pero ahora ya no se aprecia ${ }^{36}$ y los pocos que se conservan del también denominado templo de Diana de Évora (Portugal), en los que la serpiente aparece en la misma roseta central (alternando con la piña) al menos en las cuatro caras de cinco de ellos, así como en el relieve de Pancaliente, ${ }^{37}$ lugar cercano a Mérida y finalmente la serpiente representada en una de las caras de la denominada "Ara de la Salud" de Cartagena, Carthago Nova, ${ }^{38}$ ahora en el Museo Arqueológico de Barcelona y la lápida de los Voconios, en la que es un doble signo de inmortalidad.

En estos monumentos suponemos que la figura de la serpiente no está de forma casual, sino que, entre otros significados particulares, es un motivo iconográfico importante, en nuestra opinión relacionado con la propaganda augustea y altoimperial, la figura del Príncipe y su Imitatio Alexandri en relación con Cartago y Carthago Nova, el Genius Augusti-Agathodaimon de Alejandría de Egipto y el nacimiento del culto imperial.

\section{La serpiente en la propaganda augustea emeritense. Los capiteles corintios con serpiente en Mérida y Evora y el relieve de Pancaliente.}

En la Colonia Iulia Augusta Emerita, hoy Mérida, capital desde el 15 a.C. de la nueva provincia hispana de Lusitania, este motivo iconográfico de la serpiente está presente como hemos dicho en diversos ejemplares de capiteles corintios de época augusteaaltoimperial con roseta central en la que figura una serpiente enroscada, como la representada en los citados capiteles del pórtico del Foro (Fig. 2) y posiblemente debió figurar en los del denominado templo de Diana, tal vez dedicado al culto imperial en época tardoaugustea o tiberiana. ${ }^{39}$ Así, dichos capiteles son descritos como "capiteles de granito, tallados en tres bloques, con la ima folia de pencas lisas en la inferior; con la secunda folia y los caulículos en el intermedio y el superior con hélices, volutas y ábaco. Tienen una altura de $0,85 \mathrm{~m}, 0.64 \mathrm{~m}$ de altura y $0,40 \mathrm{~m}$ de grosor".

Nada se dice de la citada roseta central con el pequeño motivo serpentiforme, en nuestra opinión muy importante, como dijimos, en la propaganda imperial y el nacimiento del culto imperial, del que queremos dejar claro que se trata de un motivo iconográfico utilizado, aunque no inventado ni usado por primera vez por Augusto y su círculo, como abajo veremos, aunque sí afirmamos que lo usaron, según las diversas regiones del Mediterráneo, en provecho de dicha propaganda imperial y siguió utilizándose posteriormente, tal vez por motivos o significado diferente o simplemente como una iconografía repetida moderna, ya sin el sentido inicial que pudo tener en el

\footnotetext{
36 Álvarez Martínez - Nogales Basarrate 2000; Mateos Cruz 2007.

37 Poveda Navarro 1999; Nogales Basarrate 2000.

38 Beltrán 1947-48, 213-221, láms, 1-11, figs, 1 a y b.

39 De la Barrera 1985, 2000; Álvarez Martínez 1991, 90.
} 
mundo antiguo. ${ }^{40}$

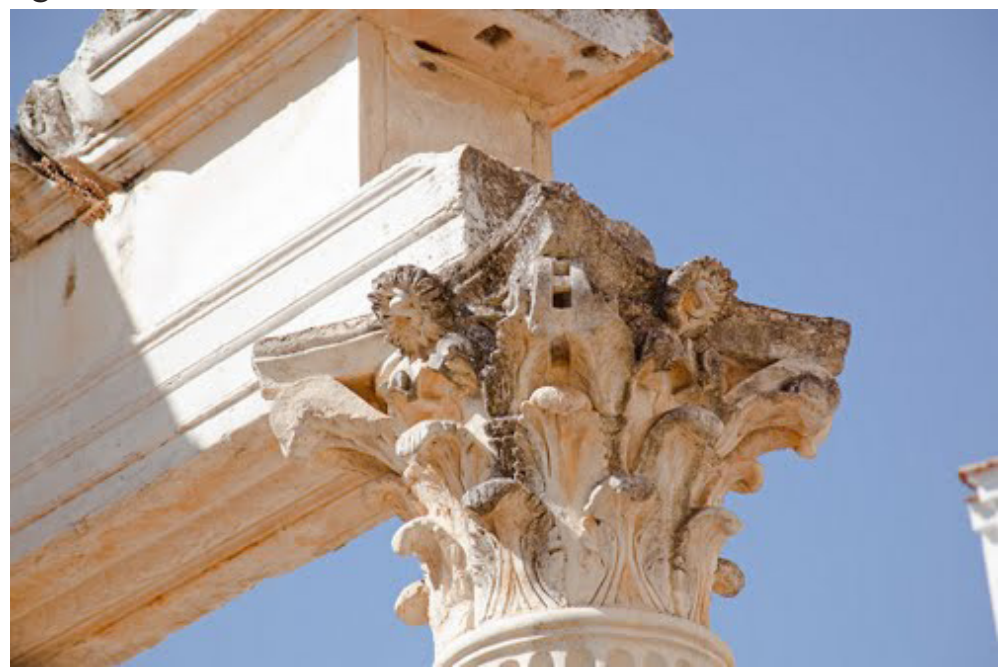

Fig. 2. Capitel corintio con motivos serpentiformes en las rosetas centrales. Foro de Mérida (España). Foto Vázquez Hoys.

Se trata en los citados casos de Mérida de un modelo de capitel corintio típico, ${ }^{41}$ de los que conocemos algunos de época augustea, utilizados, no solo en monumentos dedicados a su memoria, culto o propaganda, sino también en relación con Mérida y Agripa, el famoso yerno de Augusto, ${ }^{42}$ como los que ya en Roma capital se usaron en la parte más escondida e interna del templo de Marte del Foro de Augusto, los capiteles que enmarcan los Fasti capitolini, hoy en el Museo Capitolino, los de las columnas reutilizadas en la iglesia de Santa Sabina, el capitel de la columna frente a Santa María la Mayor o numerosos del Panteón de Agripa, entre otros muchos ejemplares conservados de los numerosísimos que debió haber, un modelo que ha permanecido en el tiempo y se usan aún en EEUU en la actualidad, aunque suponemos que perdido

40 Sobre los capiteles de Mérida: De la Barrera 1984, 72 ss; Von Hesberg 1990, 343-344. El templo de Diana tiene unas características a primera vista extrañas como ya ha destacado De la Barrera, que podría hacer pensar en dos fases en su ornamentación, época tardoaugustea o tiberiana. El edificio se realizó en pleno periodo tiberiano, época en la que comienza en Augusta Emerita de manera fehaciente el culto al emperador unido al Genio del Senado. Suponemos que las serpientes si pudieron formar parte de la ornamentación desaparecida de los capiteles corintios, donde la vimos hace muchos años, difícilmente apreciable en la actualidad, por semejanza con los del Pórtico del Foro.

41 Diana Reach: www.massrekey.com/blog/the-architectural-columns-of-uva. Elaborate corintian capital, Clark Library. University of Virginia. En Tivoli, sobre el capitel de la Palestra de la Villa Adriana. "Some scholars therefore speculate that the structure was an Isaeum of Villa Hadriani", cfr. MARI 2010, 17; MARI - SGalambro 2012, 19. La palestra se fecha entre 125 y 135 d.C. La sala con estos capiteles se supone que era un Iseum. Sobre el libro describiendo los capiteles de la termas por Andrea Palladio cfr. www.unav.es/ ha/003-ORDE/partes-capiteles-corintio. htm; www.unav.es/ha/003-ORDE/pozzo/2-POZ-1-029.jpg. Oxford Dictionary of Architecture and Landscape Architecture ; http://www.unav.es/ha/003-ORDE/freart-parallele/ frea-055.jpg; www.jamesstevenscurl.com/drawings-oxford-dictionary.php

42 CASTÁn 2013. 
ya todo sentido simbólico la figura de la serpiente, que la profesora Diana Recha atribuye a influencia egipcia, opinión que siguen los arqueólogos que estudian la palestra de la Villa Adriana de Tívoli. ${ }^{43}$

También (y repetimos que por ahora no hemos realizado un estudio exhaustivo), tienen este motivo en forma de serpiente adornando las rosetas centrales de las cuatro caras, los capiteles corintios usados en la iglesia romana de los Santi Quattri Coronati, cuyos materiales antiguos, y sobre todo los capiteles que nos interesan, parecen procedentes posiblemente de un antiguo sacellum de Diana: ${ }^{44}$ asimismo el capitel sobre la columna ante Santa María la Mayor, procedente de una basílica constantiniana y fuera de Roma capital las conocemos en diversos templos de Roma y Augusto como la Maison Carrée de Nimes en Francia o el de Roma y Augusto de Pula, en Croacia, edificado aún en vida de Augusto, ${ }^{45}$ con pequeñas serpientes en la decoración floral de los capiteles corintios, que Starack no cita, al estilo de las que aparecen en el Ara Pacis,${ }^{46}$ todo un ejemplo de arquitectura vitruviana. Este es pues un pequeño catálogo no exhaustivo de estos capiteles con serpientes que nos han llamado la atención, una relación que cualquier especialista en arquitectura romana podrá aumentar, y a nosotros nos ha servido para constatar no solo la utilización de la figura de la pequeña serpiente como motivo iconográfico y a buscarle un posible sentido en relación con Augusto, tal como hemos conocido se ha hecho con las del Ara Pacis. Y como se ha seguido utilizando como ya dijimos en época moderna en algunos capiteles usados en edificios del Nuevo Mundo, como las columnas con capitel corintio del edificio neoclásico de la Post Office de Broadway, en New York City o la Clark Library, en la Universidad de Virginia en USA. ${ }^{47}$

Acerca del posible origen y significado de este motivo serpentiforme en los capiteles corintios antiguos conocemos unas cuantas opiniones:

a.b. Sotérico y supervivencia post mortem: inmortalidad. Según el profesor Joaquín Lorda, de la Escuela de Arquitectura de la Universidad de Navarra, el capitel corintio (que a veces presenta en su roseta central el motivo serpentiforme), surgió con sus hojas de acanto en relación a cultos fúnebres o sotéricos; y aludía a algún género de vida post mortem. Es decir, fue asociado a tumbas, que se decoraban en principio con hojas de la planta de acanto (Vitrubio IV 10) y a cultos de salvación y curación, como fueron los de Apolo Soter y del médico divinizado Esculapio. De hecho, las primeras muestras de capitel con la forma que se reconoce como corintio del que se tiene noticia son el pilar central del interior del templo de Apolo Epicurio en Bassae, cerca de Figalia, en la Arcadia y los del orden interior del tholos del Santuario de Asclepio en Epidauro, además del precioso capitel que se labró antes para que sirviera de modelo. El templo de Bassae fue atribuido desde la antigüedad a Ictinos, y el segundo es ya del

43 Según Diana Reach página web cit. supra.

44 Como recuerda un texto de Cicerón, De haruspicinum responsso oratio XV 32: L.Pisonem quis nexit temporibus ipsis maximum et sanctissium Dianae, sacellum in Caeliculo sustulisse? ("¿Quién ignora que, por esta misma época, Lucio Pisón, cos. 58 a.C., destruyó en el Celiculo el santuario más importante y sagrado de la diosa Diana?").

45 STARACK 2004, 5.

46 Pallarés 2006, 14.

47 Página web nota 1 supra. 
siglo IV a.C. El capitel corintio perdió pronto esas connotaciones sotérico-fenerarias y ya en el siglo III a. C. aparece al exterior en el monumento Corégico de Lisícrates, la "linterna" de Atenas.

c. Relación con Apolo Délfico. Otra opinión es la que relaciona dicho animal y Augusto con la serpiente que acompaña al Apolo Délfico, protector de Augusto ${ }^{48}$ que le ha hecho vencer en Actium $^{49}$ y el laurel. Este árbol está figurado en el relieve de Pancaliente, que Squarciapino vincula con los ejemplares del Foro de Augusto en Roma ${ }^{50}$ denominado "Árbol de la vida", "un magnífico laurel, sobre el que se posan y revolotean pájaros, y en cuya base se enrosca una serpiente". ${ }^{51}$ El laurel es el árbol de Apolo y Augusto, ante cuya casa en el Palatino, en el 27 a.C. se plantaron dos laureles, temas que aparece en monedas de Augusto. En la iconografía augustea el laurel está presente permanentemente, con símbolo de eternidad, y se supone que dicho relieve pudo formar parte de un templum minus o templum in terris, cuyo prototipo más representativo es el Ara Pacis, a partir del cual se gestaron toda una serie de construcciones análogas vinculadas al culto imperial de la dinastía julio-claudia. ${ }^{52}$

A este respecto hay que recordar que también el laurel es el árbol de Júpiter ${ }^{53}$ como dijimos padre en forma de serpiente de Alejandro Magno. Esta imagen del relieve de Pancaliente, lugar cercano a Mérida, puesta en relación por García y Bellido con el Ara Pacis de Roma, podría interpretarse bien en relación con uno de estos dos dioses o bien considerando la serpiente como el Genio de Augusto/Agathodaimon, con el doble sentido de inmortalidad y permanencia, como hijo mítico de Apolo, como Cagnat y Poinssot interpretan la serpiente en relación a los Lares Augusti de Cartago. ${ }^{54}$ Asimismo, considerada en relación a Júpiter, estaríamos ante una imitatio Alexandri, padre mítico del héroe macedonio y una de las constantes de su propaganda política de Augusto "refundador", tanto de Roma como "nuevo Eneas", como de Alejandría como "nuevo Alejandro" y Genius Loci/Agahodaimon, o Genio del lugar, similar a la serpiente figurada en la iconografía augustea del Ara de Cartagena, la "nueva Cartago "y en la Cartago africana”, refundada por Augusto, que figura junto al águila en el frontón del altar de la gens Augusta. ${ }^{55}$

Según Poinssot, el papel decorativo de águilas y serpientes en este altar no les impide tener una significación religiosa. ${ }^{56}$ Las serpientes eran los genios tutelares de los miembros de la gens Augusta, las almas de los cuales son llevadas por las águilas al sol que las ha creado. ${ }^{57}$ Los sacra publica de la gens Iulia estaban consagradas a la gens Iulia (Serv., Aen. 316) y sobre el altar de Venus, diosa de los Julios, se ha

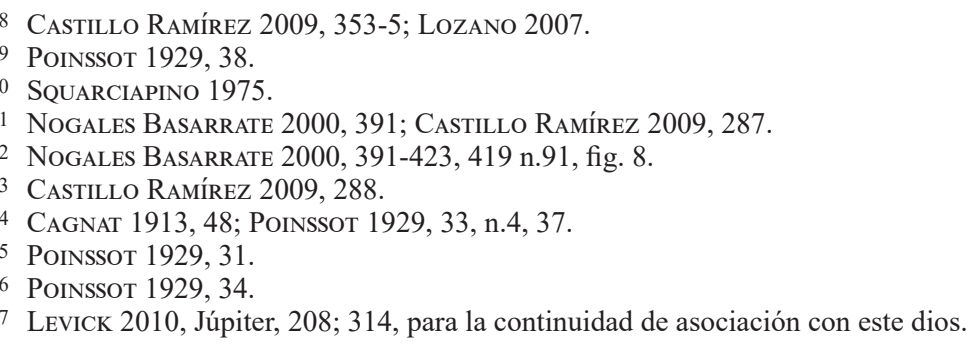


preferido a Apolo, dios del Emperador, que lo engendra en forma de serpiente ${ }^{58}$ y le ha hecho vencer en Actium, lo que ha permitido la transformación de los Lares Compitales de Roma en Lares Augusti y el nacimiento del culto a la gens Iulia. El de la gens Augusta, que era adorada con los Lares, lo fue paralelamente con los Manes del Emperador. Y los autores antiguos asimilaron posiblemente los Lares del Compitum con las almas de los difuntos divinizadas. Para Poinssot, del culto fúnebre que se les rendía era fácil pasar al de la gens Iulia o Augusta en forma de serpiente.

\section{La serpiente en cultos mediterráneos y próximo-orientales: serpiente buena- serpiente mala}

Así pues, parece que la serpiente representada tanto en monumentos como en monedas augusteas, según las diversas opiniones de distintos autores, no debió significar siempre lo mismo a lo largo de sus años de gobierno, sino que, usada como animal polisémico que es, cambiaría el significado de su mensaje dependiendo de las creencias y la relación con diversos personajes según las diferentes zonas y/o los monumentos, leyendas, creencias donde la propaganda imperial las necesitó/utilizó. Evidentemente no significaba la figura de la serpiente lo mismo en Roma e Italia que en Grecia, Macedonia, Egipto o el norte de África. Y nada tenía que ver con las creencias/adoración/dioses/diosas relacionados con este animal que parece ser existían en diversas zonas prerromanas de la Península Ibérica y nosotros hemos estudiado. ${ }^{59}$ Suponemos que aquí se pudo utilizar políticamente en época romana esta iconografía precisamente por las serpientes prerromanas y las divinidades femeninas relacionadas con ellas y/o el mundo infernal, como Proserpina, la diosa del teatro de Emerita Augusta y tal vez la acéfala conservada en el Museo Arqueológico Nacional de Arte Romano de dicha ciudad (Perséfone - Proserpina - Ataecina) hija de Deméter - Ceres, ${ }^{60}$ divinidad representada en Atenas, en época imperial en una moneda, en cuyo reverso figura con antorchas y trigo en un carro conducido por serpientes. ${ }^{61}$ Sin olvidar la relación de las divinidades infernales y el agua, puesto que el templo romano de Évora, Liberalitas Iulia (Portugal) estaba al parece dedicado con anterioridad a Diana a una divinidad de nombre desconocido relacionada con dicho elemento acuático, del que no está muy alejada la serpiente, uniéndose así elementos iconográficos y religiosos prerromanos y el nuevo culto imperial. ${ }^{62}$

En Roma, en el Ara Pacis, las pequeñas serpientes domésticas significan prosperidad y tranquilidad para Gómez Pallarés ${ }^{63}$ mientras que la cobra que va a destruir el nido la interpreta Knox como una alusión a la precariedad de la época augustea y la

58 PoINSSOT 1929, 37.

59 VÁzQuez Hoys 2005, 2006, 2006 a y b, 2007.

60 VÁzQUEZ Hoys 1981, 2007.

61 VÁzQuez Hoys 1993, 74; 2007 a.

62 MangucCi 2010, 12: “... o programa escultorico del templo que como todos sabemos, nâo sería dedicado á deusa Diana, mas sim a uma divindade aquatica e às cerimônias dedicadas ao culto dos emperadores divinizados."

63 Gómez Pallarés 2006, 60. 
inseguridad de la sucesión imperial aún en el momento de la consagración del altar y su inauguración oficial, ${ }^{64}$ ya que este animal podía ser benéfico o maléfico según su especie, al igual que en el mundo heleno, en el que era habitual utilizar su figura para representar dioses y héroes, ${ }^{65}$ e incluso la cobra podía ser también un animal benéfico, como hemos estudiado a menudo en las civilizaciones antiguas, ${ }^{66}$ así el uraeus que figura en la frente de los faraones, la antigua diosa Wadjet o "La que ama el silencio", la diosa cobra Renenutet, protectora de la necrópolis tebana que se aprecia claramente sobre la montaña del templo de Hatshepsut en Deir el Bahari. ${ }^{67}$ Con esta forma que se presentan Isis, Osiris y Zeus Amón, el padre ofídico de Alejandro Magno y el Agathos Daimon de Alejandría. ${ }^{68}$

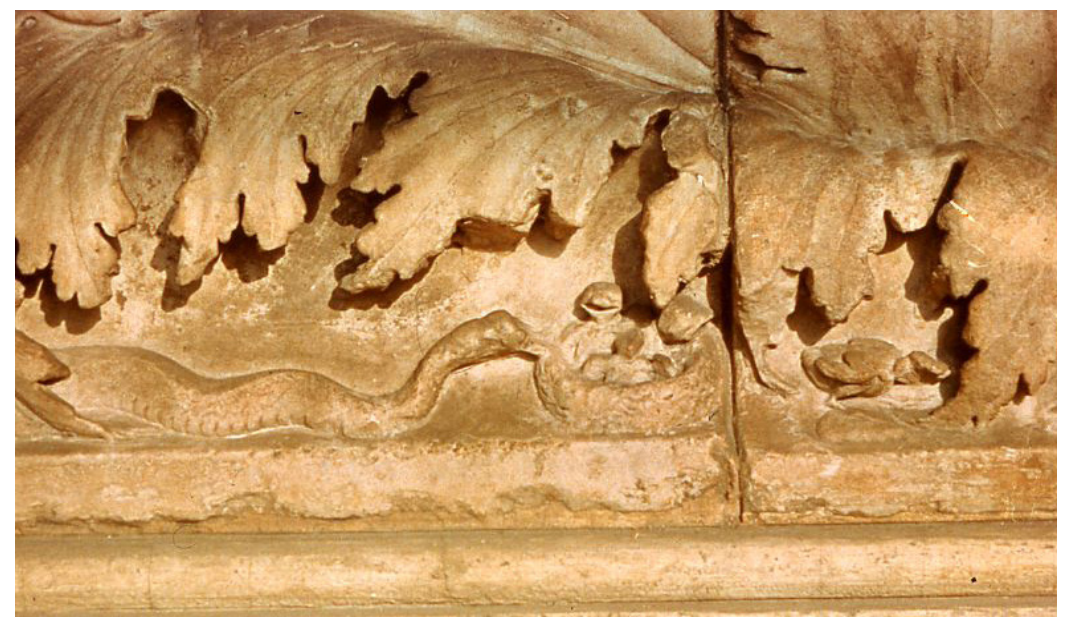

Fig. 3. Cobra en el Ara Pacis. Roma. Foto Vázquez Hoys.

\section{La serpiente, Pompeyo y Augusto en Carthago Nova. Genius Augusti, Agathodaimon e Imitatio Alexandri}

En la Península Ibérica se encuentra también el tipo de la serpiente "benéfica" en algunas monedas. Así, las de Carthago Nova (Cartagena, Murcia), donde se conocen las acuñadas por los partidarios de Pompeyo, durante las guerras contra César y luego por los duunviros quinquenales, que recogen varias veces el tipo de la serpiente como característico y peculiar, ${ }^{69}$ las monedas unciales con el tipo de la serpiente buena en la Península Ibérica, como los semises de Carthago Nova, donde en época republi-

64 KNOx 2011, 65.

65 Mitropoulou 1977.

66 VÁzQUEZ Hoys 1991b.

67 VÁzQuez Hoys 1991a.

68 VÁzQUEz Hoys 1991.

69 VÁzQuez Hoys 1993, 74-75. 
cana romana los partidarios de Pompeyo acuñaron monedas en cuyo anverso vemos una cabeza de Jano con las dos caras laureadas separadas por un ara, alrededor de la cual se enrolla una serpiente. Encima MAGN, debajo PIVS IMP. F., en el reverso, una proa de nave a la derecha. Encima EPPIVS y debajo $L E G$., aunque la serpiente también aparece en la emisión de L. Fabricius - P. Atellius (RPC 146. CNH Carthago Nova 1), considerada la primera de la ciudad. También en los ases de Carbula o las ibicencas con el cabiro con sierpe en la mano ${ }^{70}$ un tipo monetal que estudiamos en su momento, entre los que destaca sin duda el cistóforo, una antigua moneda de plata del Reino de Pérgamo, perteneciente al sistema monetario rodio, derivado del antiguo asiático del dracma, ampliamente extendida bajo la influencia de las grandes corporaciones semi religiosas, teatrales y políticas de los Dionysiakoi Technitai, el mayor numerario de plata de Asia Menor y Oriente desde al menos el siglo II a.C. y en circulación en Asia Menor en el momento de la conquista romana. En su anverso se representa la cista mística entreabierta de Dionisio que le da nombre ${ }^{71}$ de la que sale una serpiente, rodeada de hiedra con corimbos y a veces dos grandes serpientes en el reverso con las colas entrelazadas y las cabezas levantadas, ${ }^{72}$ acuñados por personajes como M. Tulio Cicerón, que figura en los cistóforos de Apamea y Laodicea ${ }^{73}$ y en los tetradracma la cabeza de Antonio a derecha rodeada de hiedra con corimbos en lugar de la cesta mística y en el reverso la de Octavia sobre la cesta mística con las dos grandes serpientes a los lados o las efigies de ambos en anverso y la cista mística en el reverso sobre una imagen de Baco-Dionysos. Tras su victoria sobre Antonio y Cleopatra en Actium, Octavio hizo acuñar cistóforos: un trióbolo o hemidracma en el sistema de los cistóforos con su cabeza hacia la derecha en anverso y la cesta mística de la que sale una serpiente en reverso, rodeada por dos serpientes más y la leyenda ASIA RECEPTA y un tetradracma con cabeza de Octavio a derecha y una larga inscripción para que nadie tuviese duda de quién era el que manejaba el asunto: IMP(erator) Divi F(ilius) CO(n)S(ul) VI LIBERTATIS POPVLI ROMANI VINDEX y en el reverso la Paz, (y la leyenda $P A X$ para que no haya ninguna duda de quién se trata), con el caduceo de Mercurio (dios del comercio), ${ }^{74}$ formado por dos serpientes en la mano derecha, rodeada de una rama de olivo y la cista mística, detrás de la que se yergue una tercera serpiente, con lo que parece decir y publicitar, más o menos, con el nuevo tipo parlante: "Las tres serpientes anteriores ahora me representan a mí y están a mi servicio" (es decir, los tesoros y el poder que en las anteriores monedas representaban).

Con estas emisiones con serpientes y esta "posible" intención, Octavio pudo difundir su particular mensaje propagandístico a todo el mundo conocido de que "ya no manda Antonio". Y al mismo tiempo proclama la libertad del pueblo romano y la paz que quiere traer con su gobierno, un mensaje que más tarde, y ya a la vuelta de

\footnotetext{
70 VÁzQuez Hoys 1993, 74-76, 79b; KAERST 1897, 51-158.

71 Daremberg-SaGlio II, 1211ss.

72 VÁZQUEZ HoYs 1993.

73 VÁzQuez Hoys 1993, fig. 9, 85, 86.

74 Sutherland 1970.
} 
sus últimas guerras, entre ellas la de Hispania, consagrará en el Ara Pacis $^{75}$ y de ahí o por lo mismo, la serpiente, (con cuya ayuda económica del templo de Lanuvium) inició su lucha, la que figura casi escondida en los diversos monumentos de principios de su gobierno, entre ellos los de Emerita Augusta comentados o los capiteles más escondidos de algunos de los primeros templos que se levantaron en su honor por todo el Imperio, entre otros los citados de Mars Ultor en Roma o el templo de Roma y Augusto en Pula.

En cuanto a Carthago Nova, no sería extraño que la propaganda augustea utilizase el mismo símbolo serpentiforme en la conocida como "Ara de la Salud", en una de cuyas caras figura la serpiente alrededor de una rama posiblemente de olivo y formen parte de la propaganda augustea y alto imperial dicho animal y las otras figuras en dicho ara representadas (Némesis de Esmirna, timón de Fortuna y cornucopia). Sobre todo por el diverso significado que dichas figuras podían representar en una zona de tanta influencia púnico-helenística y filopompeyana, siendo utilizada, por un lado, frente a la serpiente usada como dijimos por los pompeyanos como tipo de sus monedas y por otro en relación con una divinidad relacionada con las serpientes, como la que debía tener en su templo de Caravaca de la Cruz estos animales sagrados en época prerromana ${ }^{76}$ y debió ser sincretizada en época romana con Juno en la vecina Ilici. ${ }^{77}$

Asimismo la serpiente del ara de Cartagena podría representar para la propaganda imperial el Genius Augusti, o el Genio de la gens Augusta, como en el Altar de la gens Augusta en Cartago, o bien un Agathodaimon como el que aparece en la fundación de Alejandría, por lo que estaríamos ante una forma de Imitatio Alexandri y de una manera plástica de potenciar la figura imperial tanto religiosa como política y económicamente.

\section{Conclusiones. Diversas serpientes augusteas, diferentes mensajes, según las zonas}

Así pues, suponemos que en Hispania, la utilización de la iconográfía de la serpiente en diversos monumentos de época augustea y altoimperial se hizo en función del significado que ya tenía este animal en las diferentes zonas.

Tanto Lusitania como la Tarraconense en virtud de los ejemplares citados evidencian la importancia de la figura de este animal, que cuando se usa siempre es un motivo con sentido, al igual que sucede en otros motivos iconográficos augusteos. Recordemos a este respecto que recientes estudios sobre la iconografía del Ara Pacis han llevado a la conclusión de que las serpientes y/o cobra presentes en ellos tienen un significado especial y diferente entre sí, más allá del hecho de entender que dichos animales son meros elementos del paisaje idílico que representa la Aurea Aetas o la Nueva Era que produce el gobierno de Augusto, unos animales del Ara Pacis $^{78}$ que

\footnotetext{
75 VÁzquez Hoys 1993, 88, 11; KLEINER - Noe 1977, 37.

76 VÁZQUEZ HoYs 2005c.

77 VÁzQuez Hoys 2006a.

78 LEVICK 2010, 314.
} 
para Anderson forman parte de la biografía de Augusto. ${ }^{79}$ Para Gómez Pallarés ${ }^{80}$ las serpientes presentes en los paneles de Eneas y Tellus de dicho monumento están relacionadas con la fundación de Alejandría y Alejandro Magno como héroe fundador, un personaje muy admirado por Augusto. Y para Knox ${ }^{81}$ la cobra que se acerca para destruir el nido con tres crías, del que huye una cuarta, pone una nota discordante en la bucólica escena de la Aurea Aetas que representa el paisaje. Esta escena de la serpiente (cobra) y el nido, que aparece por primera vez en la Iliada, (Hom. Il. 2.30820) representaba la destrucción de la ciudad, mientras que en el Ara Pacis, Knox la interpreta o bien como una alusión al peligro que Egipto (y Antonio y Cleopatra) representaron para Octavio o bien la incertidumbre de la sucesión del príncipe.

Los términos utilizados por Horacio, cuyo Epodo I comenta Knox en el citado artículo, son indistintamente viper y anguis, sinónimos por su significado en el texto latino, aunque en inglés suele utilizarse "serpent" cuando la serpiente es benéfica, tipo serpiente de escalera, Elaphe longuissima o serpiente de Esculapio y "viper" o "snake" cuando los ejemplares representados son venenosos, como la cobra o la víbora, aunque no siempre es así, ya que el mismo Knox en el título de su trabajo utiliza el término "serpent" y también al referirse a la cobra que se aproxima al nido con polluelos en el centro del panel norte ("a serpent approaches an undeffended nest of chicks intended also to convey de potential fragility of the orden imposed on the Roman world by Augustus peace"). ${ }^{82}$

Creemos pues que la serpiente, utilizada por Augusto y su propaganda oficial en Hispania y que encontramos tanto en los capiteles corintios de Emérita, los clípeos con Zeus Amón o la Gorgona, el relieve de Pancaliente y el Ara de Cartagena, puede contener un mensaje diferente en cada zona, no solo de Hispania, sino también del Imperio Romano, dependiendo de las creencias del correspondiente sustrato prerromano de sus habitantes o los intereses político-económicos representados por este animal, como su uso en los cistóforos para "sustituir" a Antonio en Oriente o la utilizada en Ilici del culto romano a Juno y en Cartagena con sentido económico-político y religioso para superponerse a la utilizada en la causa pompeyana en Carthago Nova o, instaurando su presencia divina como Agathodaimon-Genius Augusti frente a divinidades norteafricanas en Cartago, donde la serpiente está presente varias veces en el altar de la gens Augusta.

En general la propaganda augustea utilizó el tipo de la serpiente benéfica, con significado positivo (al estilo de las pequeñas serpientes del Ara Pacis comentadas). Pero pudo tener un significado diferente al económico-político para los habitantes de Lusitania o la zona Tarraconense de Carthago Nova, donde proponemos su uso en

79 "Swans were one of the attributed animals of Apollo, the butterflies, swallows, snakes, scorpions and swans are all transformative creatures, snakes shed their skins, swallows and swans emerge from eggs and change as they mature, and scorpions at the time were fabled to emerge from the bodies of dead crocodiles, and the frogs and snakes are part of Augustus' biographical past, in Suetonius he tells of Atia, Augustus' mother, waking up in the temple of Apollo after being entered by a snake who impregnates her with the child that grows into Augustus". Cfr. ANDERSON 1998; ZANKER 2003, 58.

80 Gómez PAllarés 2006, 37.

81 KNOX 2011, 64.

82 KNox 2011, 65. 
relación con la propaganda política de Augusto y sus allegados, siempre con sentido económico/político y religioso, como una materialización del Genius Augusti o su Aeternitas (la serpiente como símbolo de la inmortalidad del personaje o su fama imperecedera). En Lusitania, en cambio, suponemos que se utilizó para reafirmar la preeminencia de Roma y Augusto y su divinidad frente a divinidades locales prerromanas, próximas geográficamente, relacionadas con la serpiente. Usando la figura de un animal sagrado en todas las culturas, servía tanto en Oriente como en Occidente, como una forma de propaganda que obedecería a la misma estrategia político-económico-religiosa imperial.

Así, mientras que para la propaganda romana Tyche-Fortuna ${ }^{83}$ y la serpiente Agathodaimon o Genius Loci, motivo helenístico bien conocido en Hispania ${ }^{84}$ son una expresión tanto de la imitatio Alexandri como del Genius Augusti, para los otros sectores de la zona este de Hispania, es la misma serpiente que figuraba en la época republicana en las monedas de los ricos magistrados monetales de Cartagena partidarios de Pompeyo, sin duda integrados pronto en el partido del nuevo Príncipe, bien aleccionado en vida por César, con el que Octavio se había reunido en Hispania y estuvo en Carthago Nova, según Nicolás de Damasco (XI 25), sin duda recibiendo de él las claves de la utilización política de los dioses como Hércules, Apolo, Venus, las posibilidades económicas de sus santuarios, como el de Hércules-Melkart de Gades, cuyas riquezas posiblemente habían sufragado su propia campaña electoral, ${ }^{85} \mathrm{o}$ de la notable influencia ideológica de los personajes históricos, en lo que César era un verdadero experto.

Según Galinsky ${ }^{86}$ Augusto, como César, sentía una gran admiración por Alejandro Magno y se le identificó con la figura del rey macedonio y Suetonio relata (Aug. 18) que visitó la tumba de Alejandro Magno y veneró su cuerpo. No hay que olvidar que Octavio es un príncipe romano de formación helenística que estudiaba en Apolonia, la ciudad de Apolo, cuando César fue asesinado y conocía bien los métodos de difusión y propaganda, de cuyo fundamento César fue un buen maestro. Y la figura de Némesis tipo Esmirna usada por la propaganda imperial que figura en dicho ara de Cartagena, está también en relación con Alejandro fundador de ciudades y la leyenda de la orden que en sueños recibió de esta diosa que figura a veces acompañada con serpientes, para fundar Esmirna ${ }^{87}$ En este caso, el mensaje difundido tiene relación con la imitatio Alexandri de Augusto, qioen con ella y la serpiente se presenta en la ciudad como "el refundador de Carthago Nova" (es decir, su nuevo dueño), unido al

83 Baynham 1999, 11: Alexander the Great: The Unique History of Quintus Curtius, 11: "Plutarch's expositions De Alexandri fortuna immediately suggest there was a corpus of literature that attributed Alexander's success to his tyche "(not at all necessarily the personalized deity)".

84 SCHRÖEDER 1996.

85 VÁzQuez Hoys 1989, pub. 1992, 1993.

86 GALINSKY 1996, 169, 199, 369.

87 Pausanias, 7.5.1: “Alexandros [Alejandro Magno] estaba cazando en el monte Pagos [cerca de Smyrna], y que después que la caza había terminado, llegó a un santuario de Némesis, y encontró allí un manantial y un plátano de sombra delante del santuario, que crecía sobre el agua. Mientras dormía bajo el plátano se dice que Némesis apareció y le ordenó fundar una ciudad allí y eliminar la ciudad antigua...así que emigraron por su propia voluntad y creen en dos Némesis en vez de en una, diciendo que su madre es Nyx, mientras que los atenienses dicen que el padre de la diosa en Rhamnos es Okeanos (Oceanus)". 
recuerdo de Escipión Africano, hijo de Júpiter - serpiente, que la había tomado en el 209 a.C., sustituyendo con "su" serpiente la utilizada por los magistrados monetales pompeyanos, Albinus, Helvius y Pollio (RPC 149-150), P. Atelius y L. Fabricius ${ }^{88}$ tal vez el tipo usado en una acuñación que proclame a Cneo Pompeyo (hijo de Pompeyo Magno) como Imperator, tras desembarcar en la ciudad en el 47 a.C. Los cuadrantes tienen nuevamente la figura de una serpiente y hay variantes $(V)-(Q V I-N) .{ }^{89}$

Aunque este altar de Cartagena para Beltrán estaba consagrado a Salus y Esculapio, dioses relacionados también con la serpiente, como el Eshmun sidonio dios de la salud y el Osiris egipcio, cultos locales arraigados en la ciudad ${ }^{90}$, Llorens Forcada $^{91}$ señala que ésta no ha de considerarse como un distintivo de la ciudad para poderlo atribuir a esta ceca, por lo que posiblemente en nuestra opinión tal vez sea mejor interpretar dicho ara no como de la Salud, sino como un monumento de época augustea tardía o tiberiana temprana, gestado en torno al culto al emperador y sus virtudes, propio de la nueva Aurea Aetas inaugurada por Augusto-Genius Augusti/ Agathodaimon. Estaría así relacionado con la retórica del lenguaje figurativo de la propaganda augustea usado también en los cistóforos citados, Emérita Augusta y el Ara Pacis, concerniente a la instauración de una nueva época de Paz-Prosperidad. Efectivamente, la figura femenina del ara de Cartagena puede ser Némesis-Paz con emblemas, símbolos y atributos también vinculados a Isis-Fortuna, Salus pública/Augusto Agathodaimon-Genius loci/Refundador de Carthago Nova y la nueva Cartago africana, ya en poder de Roma, donde se levantó el Altar de la gens Augusta con el motivo de las águilas y las serpientes. Dado que lamentablemente solo se conservan algunos capiteles corintios y otras figuras ofídicas en diversos monumentos aislados augusteos y altoimperiales, de los que la iconografía a la que nos referimos solo fue una mínima parte, aunque no por ello la menos importante, nos es imposible entenderlos en su conjunto. Pero aquí queda nuestra opinión, que ya hemos repetido en nuestra abundante bibliografía, de que la serpiente, sus mitos y su figura, no sólo en Hispania, sino también a lo largo y ancho del Mediterráneo, solo fue una pequeña parte de la impresionante máquina propagandística de imágenes e ideas transmitidas por medio de ellas, concebidas y manejadas por la camarilla de un increíble personaje: Augusto, y por él mismo.

No podremos saber nunca si efectivamente Octavio se creyó "el nuevo Eneas" refundador de Roma, y "el nuevo Alejandro" más el gran Escipión redivivo, sus hermanos, hijos como él de la serpiente (Apolo o Zeus serían indistintamente sus divinos progenitores, según conviniese). Nunca como buen político y excelente manipulador y propagandista diría ni escribiría la verdad de su pensamiento. Como Bárbara Levick afirma con razón, estamos ante un enigma. Por eso en opinión de quien esto escribe, muchos de sus actos hay que "leerlos entre líneas".

Y así, suponemos que, en realidad, puede que con la pequeña figura de esta serpiente estemos ante una de las "marcas de fábrica" usadas por Octavio y su gabinete

\footnotetext{
88 Amela Valverde 1997-1998, 141-157; 2002.

89 Kleiner - Noe 1977; VÁzQuez Hoys 1993c, fig.11.

90 Beltrán Martínez 1949, 20; 1952, 23.

91 Llorens Forcada 1994, 46.
} 
de prensa (hablando en términos actuales), para realizar una buena campaña publicitaria, a fin de disimular sus verdaderas intenciones de obtener el poder supremo, como lo fue la devolución de sus poderes al Senado y al pueblo de Roma, como hizo varias veces y finalmente sí escribió en su testamento para que quedase constancia en él, Res Gestae, ${ }^{92}$ que había sido el pueblo el que le había obligado a hacer todo lo que hizo, es decir: desmontar la República romana disimuladamente, mientras se montaba un Imperio autocrático al más puro estilo helenístico-oriental, en contra de la misma política de César. Y como los reyes orientales, se convertía en dios utilizando en su favor y en el de su familia, antiguas leyendas y el prestigio de personajes populares universales en aquel tiempo, algo que el gran Escipión, un siglo antes más o menos, no se atrevió aún a hacer y le había costado la vida a César, su padre adoptivo. ${ }^{93}$ Así pues, el cambio de culto y de poder político en cualquier lugar del Imperio no sería traumático, porque al menos iconográficamente hablando, se seguían modelos conocidos, y utilizados, no solo religiosamente, sino también en la economía, en monedas tan importantes como los citados cistóforos. ${ }^{94}$

La propaganda augustea cerraría así un poderoso círculo, político, religioso y económico, con la figura de la serpiente como una "trade mark" de Augusto, porque no hay que olvidar que en sus inicios Octavio había pedido financiación, entre otros santuarios, al de Juno Sospita, en Lanuvium, a pocos kilómetros de Velletri, lugar de origen de su familia, ${ }^{95}$ que había aportado oro para soportar la causa de Octavio en el 42 a.C. (CIL XIV,2088 = ILS 315), "a foreing Goddess through Roman eyes", la diosa de Cartago (Iuno Astarte vocantur). ${ }^{96}$

El Mediterráneo era ahora el Mare Nostrum, desde Troya y Éfeso a Alejandría, Cartago, Carthago Nova y Roma. Y en el Altar de la gens Augusta, la serpiente y el águila son tanto el poder de Roma como el citado Genio de la gens Augusta y la presencia de Augusto. ${ }^{97} \mathrm{El}$ poder político y económico lo ejercía disimuladamente un autócrata divinizado, según la más pura tradición romana del gran Escipión Africano, hijo de Júpiter serpiente, Iouis filius creditus (Ps.Aur.Vic., 49.1.; Liv., 26.4-7) que manejaba los auspicios y la ayuda divina según sus propósitos, como relata Apiano (Iberia I VI. Iber 23 y Aul. Gel., Dio, fg.57, C. Oppius, Hyginus, y Liv. 27.19), como Alejandro Magno (Liv., 38.53), igual que había hecho Escipión en la conquista de Carthago Nova en 209 a.C., porque tenía línea directa con su divino padre, Júpiterserpiente, en el Capitolio o el macedonio Alejandro Magno y Augusto, todos ellos hijos de la serpiente (el dios que los engendraba parece ser sólo una excusa) y ella era,

\footnotetext{
92 Res Gestae, diferentes ediciones: CoOley 2009, GaGé 1935, Mommsen 1865, Scheid 2007, VolkMAN 1942.

93 DeONNA 1921, 83: 32-58, 163-195; 84: 77-107.

94 VÁzQuez Hoys 1993.

95 Hermans 2012, 364.

96 Huiderg-Hansen 1982, 311-314; BleEker - Widengren 1988, 209: “At Carthage the great goddess is called Tinnit (formerly read Tanit)... It would seem that Tinnit is the specific Carthaginian form of Astarte, but strangely enough there are no theophorous names containing the element Tinnit, while there are a few with Astarte. The name seems to have originated in Carthage".

97 Cagnat 1913, Saumagne 1919, Picard 1951, Poinssot 1929.
} 
por tanto, su principal protectora (Plut., Alex. 3 y 27, Quint. Curc., X 5;98 Escipión Africano: Liv., 25, Gel., VI 1, Suet., 2.94). ${ }^{99}$ Así pues, una nueva iconografía formará parte de la nueva propaganda imperial, pero sus imágenes estaban profundamente enraizadas tanto en la romana como la del creciente Imperio, donde eran parte de creencias/ideologías/claves económicas de sus pobladores. Ellas, y entre todas, la serpiente, ayudarán a presentar a Augusto como el refundador de Roma, descendiente de los antiguos dioses, semejante a Alejandro Magno y Eneas y como el fundador de una nueva era de paz y prosperidad.

Todo esto, es decir, y para comenzar a conseguirlo, el joven se lo debía desde luego en gran medida al oro de la diosa Juno Sospita y su célebre oráculo de la serpiente en Lanuvium (Prop. 4.8; Ael. 23.1), porque su santuario financió en parte junto con otros santuarios itálicos y tal vez el de Gades, la campaña inicial de Octavio en 42 a.C., llegando su importancia económica que se sepa al menos hasta época de Adriano, ${ }^{100}$ además de la ayuda financiera de los santuarios de Antio, probablemente los de Fortuna y Esculapio, Nemi, con el famoso santuario de Diana Nemorensis, Tibur, y su riquísimo templo de Hércules, además del templo de Júpiter Capitolino de Roma, en los que Apiano asegura que existían aún en su tiempo "abundantes tesoros de dinero sagrado". ${ }^{101}$ A esto hay que añadir la estancia de al menos su padre verdadero, Turino, en Macedonia, la tierra de Alejandro, Olimpia y el Agathodaimon, donde las serpientes habían sido familiares a Alejandro Magno y no debieron ser ajenos a la financiación de la hazaña de Alejandro los tesoros de otros santuarios helenos y próximoorientales, a los que pudo acudir el macedonio en aquellos "extraños" quiebros de su viaje a Oriente, como la visita a Gordión y el curioso empeño de "sacrificar" en el templo de Heracles-Melkart de Tiro, que convertida en península desde entonces merced a la increíble obra de ingeniería llevada a cabo por lo ingenieros de Alejandro Magno para poder tomar la ciudad y "orar" como hiciera César en Gades ante Heracles Melkart. Esto por no extendernos sobre la extraña visita de Alejandro al oráculo de Amón en Siwa, empresas en Gordión, Tiro y Siwa esfuerzos sin sentido desde el punto de vista religioso pero plenamente inteligibles económicamente hablando, es decir: para buscar financiación para sus empresas, llenar las arcas, hacerse con los depósitos de lo tomado a Darío, sobre todo tras la batalla de Issos, que no solo debió proteger Filétero en Pérgamo, y buscar financiación para sus próximas empresas, como ya comentamos hace tiempo en otros trabajos.

En estos templos y sobre todo en los de Heracles-Melkart, siendo el más importante desde antiguo el de Tiro, estaban depositados muchos de los grandes tesoros del mundo antiguo en aquel momento. Y siglos más tarde estaría depositado allí el tesoro de los Lágidas, cuyo principal cliente era Cartago y las monedas de plata al

98 VÁzQUEz Hoys 1993.

99 SAINTYVES $1985,66-70$.

100 Hermans 2012, 334: “... the well-known temple of Lanuvium, which delivered, for example, enough gold to support Octavian's men in 42 BC and to make a 209 pound heavy statue during the rule of Hadrian". Octavian's men: App., BC 5.24. Statue: CIL XIV, $2088=I L S 316$.

101 VÁzQUEz HoYs 1993. 
menos seguían según Préaux el patrón fenicio. ${ }^{102}$ La infidelidad, pues, de Atia con la serpiente, como la de Olimpia o las otras humanas "casadas" con la serpiente, no solo glorificaba a los hijos de todas ellas y los hacía divinos y ricos, sino que también e indirectamente, ascendían con ellos a la gloria a sus antepasados, más aún de la mezcla divina que ya tenían en el caso de Octavio, a César y a los Julios, que ya tenían por antepasada mítica a Venus, un origen que los escritores augusteos difundieron y se escenificó en esta época, entre otros ejemplos, en la conocida estatua del Augusto de Prima Porta. De aquí a recibir culto solo había un paso. Con Venus vemos, pues, que hay una diosa más unida por la serpiente a Juno Sospita o la Juno hispanorromana de Ilici, ya que en Oriente y Cartago, la antepasada mítica de los Julios, Afrodita-Venus, era Astarté, cuyo atributo, como el de otras muchas diosas era la tantas veces aquí citada serpiente. Y sabemos que Astarté había sido sincretizada en la Cartago romana como Juno (Caelestis), Astarte vocantur. ${ }^{103}$

\begin{tabular}{|l|l|l|l|l|l|}
\hline $\begin{array}{l}\text { Serpiente y } \\
\text { divinidades } \\
\text { femeninas }\end{array}$ & Astarte & Inanna-Isthar & Ataecina & Némesis & Juno Sospita \\
\cline { 2 - 6 } & Afrodita & Artemis & $\begin{array}{l}\text { Perséfone- } \\
\text { Deméter }\end{array}$ & & Juno de Ilici \\
\cline { 2 - 6 } & Venus & Diana & $\begin{array}{l}\text { Proserpina- } \\
\text { Ceres }\end{array}$ & & Juno Caelestis \\
\hline
\end{tabular}

Tabla 1.

Es la figura de la serpiente que citamos en el Próximo Oriente y el mundo helenístico, usada también por Pompeyo y sus partidarios en las monedas de Carthago Nova, ciudad que Augusto refundaba ideológicamente con su dominio, quedándose con los negocios de los partidarios y los sucesores de Pompeyo macedónico, que también habían utilizado la serpiente en sus monedas, pero que lamentablemente, había perdido la batalla, política, económica e ideológica. Efectivamente, Pompeyo era un personaje derrotado que había querido igualarse a Alejandro Magno y había celebrado el triunfo de la conquista de Oriente y la fundación de ciudades vestido con la capa de Alejandro Magno (Ap., Mitr. 117; Plin., NH. VII 95), mientras Cicerón y Virgilio proclamaban también a Augusto, que era el ganador de la contienda final, como el único "nuevo Alejandro" (Cic., Phil. V 48; Virg., Aen. VI).

Así pues, suponemos que usando además la figura de la serpiente para su propia propaganda, un animal tan unido a su propia causa inicial y a su propia familia, como lo estaba a Alejandro Magno y a las serpientes de las diosas en Oriente y Occidente, todo seguía quedando en casa, justificado y disimulado el poder real que Octavio buscaba. La propaganda aseguraba con ella y otros símbolos más, desde luego, que, vencidos los enemigos en ambas orillas del Mediterráneo, el nuevo Príncipe asegu-

102 VÁzQuez Hoys 1993a, 320 y notas 106-10, 327 y nota 127, 329, 475 y nota 184. Macrobio, Sat. I 9.12 y Filón de Biblos 815.8 sobre el papel de la serpiente Agathos Daimon, Uroboros, los oráculos y Zeus Amón, cfr. VÁzQUEZ Hoys 1993a, 320, notas 109-110 con abundante bibliografía.

103 VÁzQuEz Hoys 1995, 81; 1999a. 
raba la paz y la prosperidad económica, la eficiencia de su gobierno y la estabilidad con la que todos soñaban y Augusto quería personificar: la utopía de la Aurea Aetas

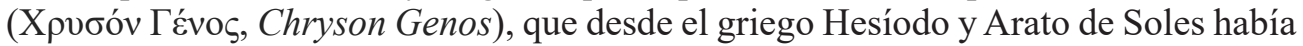
llegado a Ovidio o Virgilio, “... una dorada estirpe de hombres mortales, como yo, que crearon en los primeros tiempos los inmortales que habitaban el Olimpo. Vivieron en los tiempos de Crono, cuando reinaba en el cielo" (Trabajos y dias 109-126). La "Edad de la Inocencia" que Augusto quería conseguir), ${ }^{104}$ aunque desde luego, él mismo no practicase dicha inocencia. Todo lo aquí dicho es la suma de las opiniones que hemos recogido y en el fondo la de quien esto escribe, sabiendo que, como dijo el mismo Cicerón (Nat. Deor. I 2.5): Res enim nulla est de qua tantopere non solum indocti sed etiam docti dissentiant ("Pues no hay ningún asunto sobre el cual, no sólo los indoctos, sino también los doctos, no disientan").

\begin{tabular}{|c|c|c|c|c|}
\hline \multirow{2}{*}{$\begin{array}{l}\text { ARA PACIS } \\
\text { Aurea Aetas. } \\
\text { Augusto nuevo como } \\
\text { Eneas o Rómulo, } \\
\text { refundador de Roma }\end{array}$} & Knox (2011) & $\begin{array}{l}\text { Pequeñas } \\
\text { serpientes, cobra } \\
\text { nido }\end{array}$ & $\begin{array}{l}\text { Incertidumbre } \\
\text { época Augusto }\end{array}$ & \\
\hline & $\begin{array}{l}\text { Gómez Pallarés } \\
(2006)\end{array}$ & \begin{tabular}{|l|} 
Pequeñas \\
serpientes
\end{tabular} & \multicolumn{2}{|c|}{$\begin{array}{l}\text { Prosperidad, benéficas, con fauna } \\
\text { y vegetación personificadas por } \\
\text { Tellus/ Abundancia, la actual Aurea } \\
\text { Aetas y la refundación de Roma }\end{array}$} \\
\hline \multirow{4}{*}{$\begin{array}{l}\text { ARA DE } \\
\text { CARTAGENA }\end{array}$} & \multirow[t]{3}{*}{ Beltrán (1947-48) } & \multirow[t]{3}{*}{ Serpiente } & Salus/Esculapio & \\
\hline & & & Eshmun/Osiris & \\
\hline & & & Astarte & \\
\hline & \multirow[t]{3}{*}{$\begin{array}{l}\text { Vázquez Hoys } \\
\text { (2014) }\end{array}$} & \multirow{3}{*}{ Serpiente } & \multicolumn{2}{|c|}{$\begin{array}{l}\text { Genius loci, Agathos daimon, } \\
\text { Imitatio Alexandri, Genius } \\
\text { Augusti. }\end{array}$} \\
\hline \multirow{2}{*}{$\begin{array}{l}\text { Capiteles corintios } \\
\text { con serpiente en época } \\
\text { Augusto, diversos } \\
\text { templos/monumentos. }\end{array}$} & & & \multicolumn{2}{|c|}{$\begin{array}{l}\text { "Marca de fábrica" de la } \\
\text { propaganda económica augustea } \\
\text { / Santuarios y monedas con } \\
\text { serpientel. Mensaje político- } \\
\text { económico }\end{array}$} \\
\hline & & & \multicolumn{2}{|c|}{$\begin{array}{l}\text { Asimilación divinidades locales } \\
\text { relacionadas con serpientes }\end{array}$} \\
\hline ARA DE CARTAGO & Poinssot (1929) & $\begin{array}{l}\text { Serpiente Genius } \\
\text { Augusti, Manes } \\
\text { Gens Augusta. }\end{array}$ & & \\
\hline
\end{tabular}

Tabla 2.

104 BAUZÁ 2008, 34. 


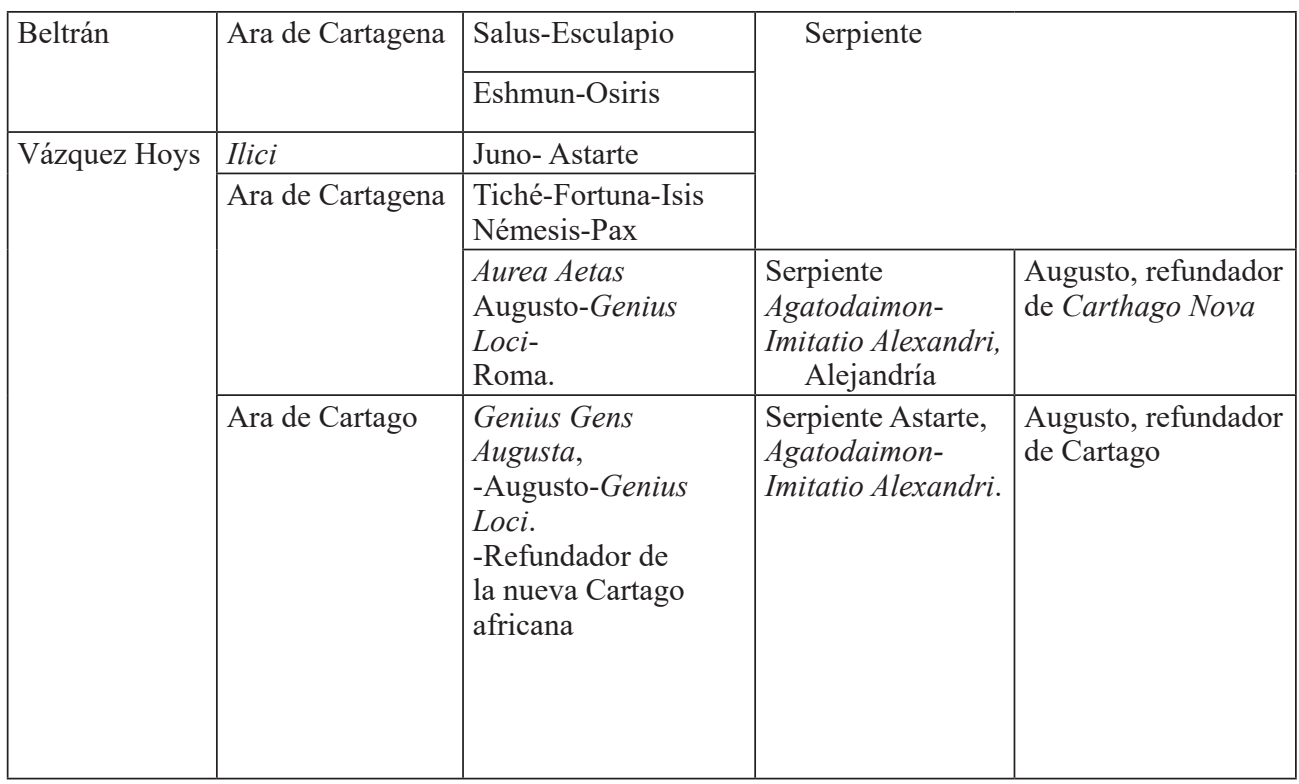

Tabla 3.

\section{Bibliografía}

Amela Valverde, L.

(1997-98) "La acuñación de Albinus y Helius Pollio II(Qu) de Cartagonova (RPC 149150) y su relación con la causa pompeyana", Ann. Murc. 13-14, 141-157.

(2000): “Acuñaciones de Cneo Pompeyo hijo en Hispania", Numisma 244, 7-33.

(2002): Las clientelas de Cneo Pompeyo Magno en Hispania, Barcelona.

Álvarez Martínez, J. Ma (1992): "El templo de Diana", [en] Templos romanos de Hispania, (=Cuadernos de Arquitectura romana 1), 83-93.

Álvarez Martínez, J. Ma - Nogales Basarrate, T. (2003): Forum Coloniae Avgvsta Emeritae - Templo de Diana, Mérida.

Anderson, J. C. (1998): “The Ara Pacis Augustae: Legends, Facts, and Flights of Fancy", [en] M. T. Boatwrigh - H. B. Evans (eds.), The Shapes of City Life in Rome and Pompeii: Essays in Honor of Lawrence Richardson Jr., on the Occasion of His Retirement, New York.

BAuZÁ, U. F. (2008): Virgilio y su tiempo, Madrid.

Baynham, E. (1999): Alexander the Great: The Unique History of Quintus Curtius, Ann Arbor, MI.

Bayet, J. (1971): Croyances et rites dans la Rome antique, Paris.

Beltrán, A.

(1947-48): "El ara romana del Museo de Barcelona y su relación con el culto de la Salud y Esculapio en Carthago Nova", Ampurias 9-10, 213-221. 
(1947): "Las monedas romanas de Cartagena según sus series de monedas y lápidas latinas", [en] Actas y Crónica del Congreso de Albacete, 306-325.

(1949) (2010): "Monedas de personajes pompeyanos en relación con Cartagena", [en] Crónica del V Congreso Arqueológico del Sudeste Español y del I Congreso Nacional de Arqueología, Congreso Arqueológico del Sudeste Español 5, Murcia, 246-258.

Bertrand-ECANVIL, E. (1994): "Présages et propagande idéologique: à propos d'une liste concernant Octavien Auguste", MEFRA 106, 487-531.

Bleeker, CL. J. - Widengren, G. (1988): Historia Religionum, 1. Religions of the Past. Leiden.

BLoch, R. (1968): Los prodigios en la antigüedad clásica, Buenos Aires.

Bodson, L. (1978): 'Iera Zoia. Contribution á l'studio de la place de l'animal dans la religion grecque ancienne, Bruxelles.

Cagnat, R. (1913): "Un temple de la Gens Augusta à Carthage”, CRAI 57-9, 680-686.

Carabia, J. (1977) : “Les présages dans les Vies des Douze Césars de Suétone”, Trames 2, 9-31.

Castán, S. (2013): "Marco Agripa y Augusto. Poder, Imperium Maius y problema sucesorio en el contexto de las tensiones República-Principado", Rid Rom., Madrid, 196-290.

Castillo Ramírez, E. (2009): Propaganda politica y Culto Imperial en Hispania, de Augusto a Antonino Pio: Reflejos urbanísticos, Madrid.

Castriota, D. (1995): The Ara Pacis Augustae and the imaginery of abundance in later Greet and early Roman Imperial Art, Princenton, NJ.

CizeK, E. (1977): Structures et idéologie dans les “Vies des Douze Césars” de Suetone, Bucarest- Paris.

CoArelli, F. (1983): [en] AA.VV., Città e architettura nella Roma imperiale, Roma, 41-46.

Cooley, A. (ed.) (2009): Res Gestae divi Augusti, Cambridge.

Crawford, M. (1975): Roman Republican Coinage, Cambridge.

De la Barrera Antón, J. L.

(1985): Los capiteles romanos de Mérida, Mérida.

(2000): Decoración arquitectónica de los Foros de Augusta Emerita, Leiden.

Del Hoyo Calleja, J. (2011): “Aprovechamiento político de los dioses por Augusto y su tiempo", [en] Mites, ofrenes funeràries i monedes. XV Curs d'història monetària d'Hispània, 45-53.

Deonna, W. (1921): "La légende d'Octave-Auguste, dieu, sauveur et maître du monde", $R H R$ 83, 32-58,163-195; 84, 77-107.

Floriani SQuARCIAPINO, M.

(1975): "Ipotesi di lavoro sul gruppo di sculture di Pan Caliente", [en] Augusta Emérita. Actas del Simposio internacional conmemorativo del Bimillenario de Mérida, Madrid, 5562.

(1982): “Cultura artística di Mérida romana”, [en] Homenaje a J. Álvarez Sáenz de Buruaga, Madrid.

GaGÉ, J. (1935): Res gestae divi Augusti ex monumentis Ancyrano et Antiocheno latinis, Paris.

Galinsky, K. (1996): Augustan Culture. An Interpretive Introduction, Princeton, NJ. 
GIL FERnÁNDEZ, L. (2002): "Los ensueños de griegos y romanos. Esbozo de tipología cultural”, [en] R. Teja (coord.), Sueños, ensueños y visiones en la Antigüedad cristiana y paga$n a$, vol. II, Codex 18, Sta. María la Real, 11-36.

Gómez Pallarés, J. (2006): “Serpientes en el Ara Pacis de Augusto: una interpretación simbólica", Faventia 28, 1-2, 59-65.

GonzÁlez Herrero, M.

(2002): “Origen familiar y procedencia: El ejemplo de la rama familiar A de la familia Roscia”, [en] XII International Congress of Greek and Latin Epigraphy, Barcelona, 621-627. (2010): "Clarissimi Lusitani en los círculos dirigentes de Roma. Contribución al estudio del proceso de romanización en Lusitania", [en] Proceedins of the XV World Congress, Oxford, 53-58.

GRAndet, P. (1986) : “Les songes d'Atia et d' Octavius. Note sur les rapports d'Auguste et de l'Egypte", RHR 203I, 365-379.

GRIMAL, P. (2008): Diccionario de mitología griega y romana, Barcelona.

Gurval, R. A. (1998): Actium and Augustus: The Politics and Emotions of Civil War, Michigan.

Hermans, R. (2012): “Juno Sospita: “A foreign Goddess through Roman eyes", [en] S. Roselaar (ed.), Processes of Integration and Identity in the Roman Republic, Leiden, 327-366.

Huiderg-Hansen, F. O. (1982): La déesse TNT: une Etude sur la réligion canaanéo punique, Copenhague.

Justo Elvira, A. (2011): “Apolo versus Dioniso. Augusto versus Marco Antonio. Augusto a través de los denarios”, Arte, arqueología e historia 18, 121-124.

Kaerst, J. (1897): "Die Begrundung des Alexander und Ptolemaeerkultes in Aegypten", Rhein. Mus. 52, 51-58.

Karsten Dahmen, K. (2007): The Legend of Alexander the Great on Greek and Roman Coins, New York.

KLeiner, F. S. - Noe, S. P. (1977): “The Early Cistophoric Coinage”, ANSNS 14, New York.

Knox, P. (2011): "The Serpent in the Augustan Garden: Horace's First Epode and the Ara Pacis", The Classical Journal 107/1, 65-71.

KraUss, F. B. (1930): An Interpretation of the omens, portents and prodigies recorded by Livy, Tacitus and Suetonius, Philadelphia.

Lenormant, F.: “Cistophori”, DAREMBERG-SAGLIO, II.I, 1211 -1213.

LEVICK, B. (2010): Augustus, Image and Sustance, Harlow/London/New York.

LORSCH, R. S.

(1993): Omina imperii: the omens of power received by the Roman emperors from Augustus to Domitian, their religious interpretation and political influence, Ann Arbor, MI.

(1997): “Augustus conception and the Heroic Tradition", Latomus 56, 790-799.

(2000): The Propaganda of Omens", [en] R. Lorch - J. Isager (eds.), Divination and Portents in Roman World, Odense.

LORDA, J. (2012 ): http://www.unav.es/ha/003-ORDE/partes-capiteles-corintio.htm.

LOZANO, F.

(2000): "Historias fabulosas: Un aspecto de la construcción de la divinidad de los emperadores romanos", Habis 39, 153-162. 
(2007): “Los Agones de los Augustos en Atenas", [en] Mayer et alii. (eds.), Actas II, XII Congressus Internationalis Epigraphiae Graecae et Latinae, Barcelona, 851-856.

Llorens Forcada, M. M. (1994): La ciudad romana de Carthago Nova: las emisiones romanas, Murcia.

Mangucci, C. (2010): Guia de Museus do Alentejo, Alentejo.

Mateos Cruz, P. (2007): El Foro Provincial de Augusta Emerita: Un conjunto monumental de Culto Imperial, (=Anejos de AEspa XLII), Madrid.

MARI, Z. (2010): "Villa Adriana: recenti scoperte e stato della ricerca", Ephemeris Napocensis 20, 7-37.

Mari, Z. - Sgalambro, S. (2012): “The Antinoeion of Hadrian's Villa: Interpretation and Architectural Reconstruction", AJA, 10-24.

MetaxÁ, L. (1823): Monografia de 'serpenti di Roma e i suoi contorni, Roma.

Mitropoulou, E. (1977): Deities and heroes in the form of snake, Athens.

Mommsen, Th. (1865). Res gestae Divi Augusti ex monumentis Ancyrano et Apolloniensi, Berlin.

Nogales Basarrate, T. (2000): "El relieve histórico de M. Agrippa, los relieves de Pan Caliente y el Altar del Foro emeritense", Espacio, Tiempo y Forma, Serie II, Historia Antigua 13, 391-423.

Poveda Navarro, A. (1999): Reinterpretación del relieve histórico emeritense de M. Agripa a partir de un nuevo fragmento", Espacio, Tiempo y Forma, serie II 12, 389-405.

PicARD, C. (1951): Carthage, Paris.

Poinssot, L. (1929): L'autel de la Gens Augusta à Carthage, Paris -Tunis.

ReHAK, P. (2001): "Numa or Aeneas? Rethinking the Meaning of the Ara Pacis Augustae", The Art Bulletin 83/2, 190-208.

REQUENA JiMÉNEZ, M.

(2001): "El emperador predestinado. Los presagios de poder en época imperial romana. IV. Augusto, el monarca de la concordia ", Cuadernos de la Fundación Pastor, 147-199.

(2003): Lo maravilloso y el poder: Los presagios de imperio de los emperadores Aureliano y Tácito en la Historia Augusta, Valencia.

RoDDAz, J. M.

(1984): Marcus Agrippa, Paris-Roma.

(1990): “Agrippa et la Péninsule Ibérique”, [en] Bimillenario di Agrippa, Génova.

(1993): “Augusto y la Península Ibérica”, Anas 6, 111-126.

Romeo, I. (1998): Ingenuus Deo. L'immagine di Agrippa, Roma.

SAINTYES, P. (1985): Las madres vírgenes y los embarazos milagrosos, Madrid.

Saumagne, CH. (1919): “Autel de la Gens Augusta découvert à Carthage”, Bulletin archéologique du Comité des travaux historiques et scientifiques, 186-190.

ScheID, J. (ed.) (2007): Res Gestae Divi Augusti: hauts faits du divin Auguste, Paris.

SchÖDER, S. F. (1996): "El “Asclepio” de Ampurias: ¿una estatua de Agathodaimon del último cuarto del siglo II a. C?”, [en] J. Massó - P. Sada (eds.), Actes II Reunió sobre escultura romana a Hispania, Tarragona, 223-237.

Starak, A. (2004): The temple of Augustus, Pula.

Strong, E. (1929): Roma Antica, Bergamo. 
Sutherland, C. H. V. (1970): The cistophori of Augustus, London.

Syndeham, E. A. (1952): The coinage of the Roman Republic, Spink.

Torelli, M. (1992): “Topografía e iconología. Arco di Portogallo, Ara Pacis. Ara providentiae, Templum Solis", Ostraia 1/1, 105-131.

VÁzQuez Hoys, A. M ${ }^{\mathrm{a}}$

(1981): "La serpiente en el mundo antiguo I. La serpiente en las religiones mediterráneas", $B A A A 14,33-39$.

(1989, 1992): "Lixus en el panorama religioso fenicio de Occidente", [en] Congreso Internacional Lixus, bilan et perspectives, (=Collection de l'École Française de Rome 166), Roma, 103-113.

(1992): “La serpiente en la antigüedad: ¿Genio o demonio?”, [en] I Encuentro-Coloquio de Arys. Jarandilla de la Vera, Madrid, 81-134.

(1993): "La serpiente en las monedas. Transmisión iconográfica de una antigua creencia", Espacio. Tiempo y Forma. Serie II. H ${ }^{a}$ Antigua 6, 59-98.

(1993a): Grecia desde el siglo IV. Alejandro Magno. El Helenismo, Madrid.

(1993b): "El templo de Herakles Melkart y su papel económico", [en] Studis d'Historia Economica", Economia i Societat a la Prehistoria i Mond Antic, Ibiza.

(1993c): "Perduración y cambio del significado de la serpiente en las monedas antiguas", [en] C. Blánquez Pérez - J. Alvar Ezquerra - C. G. Wagner (eds.), Formas de difusión de las religiones antiguas, 161-171.

(1994): "La serpiente en las fuentes epigráficas hispanas”, [en] L'Africa, La Gaule, la Religion à l'epoque romaine. Hom. à Marcel Le Glay, Revue des Études latines, vol. 1, Bruxelles, 568-586.

(1995): Diana en la religiosidad hispanorromana. I. Las fuentes. Las diferentes diosas, Madrid.

(1997): “A propósito de las serpientes en las cerámicas ibéricas de Elche”, [en] Actas XXIII Congreso Nacional de Arqueología, 1, Elche, 329-338.

(1999): Diana en la religiosidad hispanorromana II: Diana de Segobriga, Madrid.

(1999a): "Divinidades femeninas romanas en Hispania y sus antecedentes orientales: Diana y Venus", [en] Treballs del Museu Arqueologic d'Eivissa e Formentera, (=Trabajos del Museo Arqueológico de Ibiza y Formentera 43), 103-135.

(1999b): "Diana in roman Spain. Towards a new interpretation" [en] XI Congress of FIEC, Kavala.

(2005): Historia del Mundo antiguo II. Macedonia. Alejandro Magno. El Helenismo. Cartago. Etruria. Roma I, Madrid.

(2005a): “Olimpia de Épiro" Revista de Arqueología 26/289, 36-45.

(2005b): "Olimpia de Épiro (375-315 a.C.): su realidad histórica”, Revista de Arqueología, 26/290, 32-39.

(2005c): "Las mediadoras con lo divino en la Iberia prerromana", [en] Congreso Internacional sobre Historia de las religiones Homo religiosus. Mediadores con lo divino en el mundo mediterráneo antiguo, Palma de Mallorca.

(2006): "Los altares en forma de lingote / piel de toro y las serpientes. Una hipótesis sobre su posible relación con las operadoras cultuales femeninas en la Península Ibérica en época prerromana", Rivista di studi fenici 34/2, 121-138.

(2006 a): "El culto a Juno en Hispania y la implantación del poder romano en la Península Ibérica”, Comunicación al VII Congreso Nacional de la Sociedad Española de Ciencias de las Religiones (SECR), Religión y Poder, Toledo.

(2006 b): Historia de las Religiones Antiguas I. Mesopotamia, Madrid. 
(2007): "Los posibles cultos a la serpiente y los celtas en la Península Ibérica", [en] VXornadas do Instituto de Estudios Celtas, Samahin, Pasado y presente de los estudios celtas, Ortigueira, 349-364.

VÁzquez Hoys, A. Ma - MuÑoz García-VAso, J. (1990): "Representaciones de serpientes en la iconografía mitraica", Espacio, Tiempo y Forma, Serie II, Ha Antigua 3, 85-116.

VÁzquez Hoys, A. Ma - Poveda Navarro, A. (2000): "Incidencia púnica y oriental en el panorama religioso autóctono del sureste de la península Ibérica”, [en] M. Barthélemy $\mathrm{M}^{\mathrm{a}}$ E. Aubet (eds.), Actas del IV Congreso Internacional de Estudios Fenicios y Púnicos, vol. 2, 697-708.

Volkman, H. (1942): Res gestae Divi Augusti. Das Monumentum Ancyranum, Leipzig.

Von Hesberg, H. (1990): “Bauomament ais kulturelle Leitform”, [en] Stadtbild und Ideologie, München, 343-344.

Yacoub, M. (1993): Le musée du Bardo, Tunis.

ZANKer, P. (1992): Augusto y el poder de las imágenes, Madrid. 